\title{
The ameliorating effect of some immune- stimulants on bursal and tracheal lesions of broiler chickens challenged with ND virus
}

\author{
Marwa F. Ali ${ }^{1 *}$ D, Mohamed S. Abdel Hafez ${ }^{2}$ and Moemen A. Mohamed ${ }^{3}$
}

\begin{abstract}
Background: Nowadays, immuno-stimulants have great importance in improving the immune system and minimising the effect of infectious diseases in poultry flocks. This study was designed to demonstrate the impact of using different immunestimulants on the reduction of the harmful implications of virulent ND virus through evaluation of histopathological lesion scores on bursa and trachea of vaccinated and infected broiler chickens with Newcastle disease (ND).

Results: Eighty Ross breed broiler chicks at the age of 1 day were randomly divided into four groups, each group formed of 20 birds. Group I was vaccinated against Al, ND and IBD and used as a control. Groups II, III and IV were immunised as group I and also had immuno-stimulant supplement, Imutrix ${ }^{\circledR}$ (oregano oils plus ß-glucan), Evit liquid ${ }^{\circledR}$ (Vitamin E plus selenium) and Immunair 17.5 (Propionibacterium acnes and E. coli lipopolysaccharides), respectively. All groups were experimentally infected with virulent ND virus at the age of 28 days. The morbidity rates for groups I, II, III and IV were 15\%,5\%,5\% and 10\% respectively. Histopathological examination of bursa revealed hyperplasia of lymphoid follicles in group I which became more evident in groups II, III and IV. Group III showed hyperplasia of tracheal epithelium with lymphocytes and heterophils infiltration in lamina propria. CD79A-positive cells were significantly higher in bursa of group III in comparison to other groups during an immunohistochemical examination.
\end{abstract}

Conclusion: It was concluded that Evit liquid ${ }^{\circledR}$ (vitamin E plus selenium) supplementation might have potent immunomodulatory effect in chickens.

Keywords: Immuno-stimulants, Broiler chickens, Newcastle disease virus, Immune-histochemistry

\section{Background}

Vaccination against common diseases is the backbone in preventive measures against various disease outbreaks. Even with the use of the available vaccines, disease outbreaks are still attacking poultry flocks due to a variety of stresses of intensive production systems, high density, nutritional and antibiotic administration as well as immunosuppression that adversely affect the immune status of the birds (Dhama et al., 2013; Yamuna \& Thangavel, 2011).

When vaccinated birds are challenged with virulent ND viruses, replication and shedding of the virus occur, so vaccination prevents disease, but not an infection. Therefore, there is a need to maximise the immune

\footnotetext{
* Correspondence: Marwafa28@gmail.com

${ }^{1}$ Department of pathology and clinical pathology, Faculty of Veterinary

Medicine, Assiut University, Assiut 71526, Egypt

Full list of author information is available at the end of the article
}

response of $\mathrm{ND}$ and $\mathrm{AI}$ vaccines for obtaining sufficient antibody titers that can minimise viral replication. Therefore, immune-stimulants have been used as an adjuvant to gain long-lasting humoral and cellular immune responses and enhancement the response of vaccines. Strengthening of specific immunity (humoral and cell-mediated) will maximise the animal's ability to fight diseases (Hou et al., 2016; Yu, Shi, \& Hu, 2015).

Oregano essential oils (OEO) are obtained from Origanum vulgare plants (leaves and flowers). They contain more than 30 components, most of which are carvacrol and thymol that form about $78-82 \%$ of oregano essential oil (Al-Bandak \& Oreopoulou, 2007). Oregano essential oils have good antioxidant effects, which suppress the oxidative reactions that exert on phospholipid membranes (Rhee, Anderson, \& Sams, 1996; Walter \& Bilkei, 2004). ß-glucans are glucose molecules that considered 
the base components of the cell wall of different bacteria, fungi, algae and yeast (Volman, Ramakers, \& Plat, 2008). ß-glucans stimulated the immune cells, macrophages, dendritic cells neutrophils, B cells, $\mathrm{T}$ cells and natural killer cells (Kim et al., 2011).

Vitamin E, a fat-soluble vitamin, has immune-stimulant effects as well as antioxidant properties and improves cellular and humoral immune responses (Khan et al., 2012; Konjufca, Bottje, Bersi, \& Erf, 2004; Leshchinsky \& Klasing, 2001).

Immunair $17.5^{\circ}$ (Propionibacterium acnes and E. coli lipopolysaccharides) is one of the commercial products newly available in the Egyptian market as nonspecific immune-stimulant for the chicken herds. P. acnes is a Gram-positive, non-spore forming adaptable bacteria (Martín-Rabadán et al., 2008). P. acnes is an effective potentiate of macrophage, lymphocyte, natural killer cells and cytokine release in the examined lab animals (Tizard, 2009). Lipopolysaccharides are the significant components of the outer membrane of Gram-negative bacteria, encourage strong immune responses. Lipopolysaccharides of $E$. coli (LPS) had a role in releasing IL-1, IL-6, or tumour necrosis factor (TNF) by macrophages (Silhavy, Kahne, \& Walker, 2010).

This study was conducted to investigate the effect of different immune-stimulants on reducing the harmful impact of virulent NDV of the targeting tissues of the NDV.

\section{Methods}

\section{Experimental design of broilers and management}

Eighty (Ross breed of mixed sex) broiler chicks at the age of 1 day were weighted just after arrival and randomly divided into four groups $(20$ birds for each group). Birds were raised in hygienic conditions for 35 days, dry floor and had free access to feed (El Wadi feed company starter, grower and finisher feed) and clean water throughout the experiment. The temperature of the rising was $32{ }^{\circ} \mathrm{C}$ at the beginning of the brooding period then was gradually decreased to $24{ }^{\circ} \mathrm{C}$ in the fourth week which was still constant until the end of the experiment. The lighting program was 23-h lightness and $1 \mathrm{~h}$ of darkness.

\section{Vaccination program and immune-stimulants}

- Birds of all groups were vaccinated against AI (Nobilis, H5N2), and vaccination was given one S/C shot at the 5th day of age using killed H5N2) ND via drinking water was administered at the 7th day of age (HB1, Pfizer Co.), 15th day of age (LaSota, Pfizer) and at 22nd day of age (clone 30, Izovac Co.), and at the 13th day of age with intermediate strain vaccine of Gumboro via drinking water.
- Group I was the control group (vaccinated and nontreated with any immune-stimulant).

- Group II was additionally treated with (Imutrix ${ }^{\circ}$ ) in a dose of $1.5 \mathrm{ml} / \mathrm{L}$ of the drinking water for $24 \mathrm{~h}$ at the first 3 days of every week for 5 weeks. Imutrix ${ }^{\circ}$ (ELT company, South Korea) is a commercial name containing purified $ß$-glucan $11 \mathrm{~g}$ and oregano essential oils $120 \mathrm{~g}$ (carvacrol $60 \mathrm{~g}$ plus thymol $3.6 \mathrm{~g}$ ) in demineralised water up to 1-1 emulsifiers.

- Group III was treated with vitamin E and selenium. The vitamin and selenium (Tecnozo Co., Italia) were produced under the trade name Evit liquid.

- Group IV was supplemented with Immunair 17.5 with the same way of administration of group II. Immunair 17.5 (LABORATORIOS CALIER SA) which contains inactivated cells of Propionibacterium acnes $0.17 \mathrm{mg}$, lipopolysaccharide from E. coli $0.05 \mathrm{mg}$, thiomersal $0.1 \mathrm{mg}$ and Excipient q.s $1 \mathrm{ml}$.

\section{Challenge trial}

- All birds in all groups were challenged at day 28 of age via oculonasal with $50 \%$ embryo infecting dose titer of $8 \log$ 10/0.1 ml velogenic strain of NDV, and phosphate-buffered saline was used as a diluent for the infective dose.

- Birds were observed daily after challenge for the presence of NDV clinical manifestations or mortality.

\section{Histopathological examination}

Fresh specimens from bursae and trachea of chicken of all experimental groups were collected and fixed in 10\% neutral-buffered formalin. The tissues were dehydrated in a graded alcohol series, cleared with methyl benzoate, embedded in paraffin wax, sectioned at 4- $\mu \mathrm{m}$ thickness and stained with haematoxylin and eosin for histopathological examination by light microscopy (Olympus CX31, Japan) and photographed using digital camera (Olympus, Camedia C-5060, Japan) (Bancroft \& Stevens, 1982).

Bursal histopathological lesions were scored according to Muskett, Hopkins, Edwards, and Thornton (1979) as follows: no damage $=0$; mild necrosis in isolated follicles $=+$; moderate generalised lymphocyte depletion of isolated follicles =++; over $50 \%$ of follicles with severe lymphocyte depletion $=+++$; skeleton of follicles only remaining with few lymphocytes and an increase in connective tissue, cysts, and thickened infolded epithelium $=++++$; and loss of all follicular architecture with thickening of interfollicular stroma $=+++++$.

Lesions in trachea were scored in the scoring system according to Reali-Forster et al. (1996), assessing the epithelial injury as no damage $=0$, mild $=1$, moderate $=2$ 
and severe $=3$. In submucosal edema, inflammation and haemorrhage, absent $=0$, mild $=1$, moderate $=2$ and severe $=3$. One mean score was applied to each field of view. The scores from other fields of view were added to arrive at a final mean score for the whole slide.

\section{Immunohistochemistry investigations}

Bursal sections were examined to identify primary antibodies for CD79 (B-lymphocytes). Primary antibodies for CD79 were obtained from Novus Biologicus company. The staining was performed using Power-Stain ${ }^{\text {TM }} 1.0$ Poly HRP DAB, and the manufacturer's instructions were applied.

The procedure is as follows: formalin-fixed bursae were thin-sectioned as 3- $\mu$ m-thick. Paraffin-embedded tissue sections were deparaffinised and hydrated then washed by distal water. Antigen retrieval was applied in a water bath using citrate buffer ( $\mathrm{pH} \mathrm{6)}$ for $20 \mathrm{~min}$. The endogenous peroxidase activities were removed with $3 \%$ hydrogen peroxide $\left(\mathrm{H}_{2} \mathrm{O}_{2}\right)$. Sections were incubated with diluted polyclonal primary antibody for $1 \mathrm{~h}$ at room temperature in a humidified chamber. After being rinsed three times for $5 \mathrm{~min}$ each with PBS, the sections were incubated with poly-HRP conjugate for $15 \mathrm{~min}$ at room temperature. The mixture of $\mathrm{DAB}$ chromogen and $\mathrm{DAB}$ substrate were added to parts and incubated for $10 \mathrm{~min}$. Sections were washed by distilled water then counterstained with haematoxylin (Anis et al., 2013).

\section{Morphometrical analysis}

The CD79A positive cells were counted in ten fields of the histological sections using digital an Axiostar plus microscope (Carl Zeiss, Thornwood, NY, USA) interfaced with an Axiostar plus digital camera and Axiovision 4.1 software (Carl Zeiss) at a magnification of 100 . CD79A were diffusely distributed, and their relative frequency per focus was calculated according to the point count method (Weibel, 1969).

\section{Statistical analysis}

Statistical analysis was performed by using the Statistical Package for the Social Sciences (SPSS), Version 16 for Windows. Data were expressed as mean \pm SD. The difference in the mean number of CD79A-positive cells in bursa of Fabricius in different groups was evaluated by the Kruskal-Wallis test (nonparametric test for several independent samples) (Inc, 2007).

\section{Results}

\section{Morbidity rate}

The morbidity rate was 5\% in group II (treated with Imutrix $^{\circ}$ ) and group III (treated with vitamin E and selenium). Morbidity rate increased in group IV (treated with Immunair) reaching 10\%, and the highest morbidity rate was mentioned in group I (control group) with $15 \%$.

\section{Histopathological examination Bursa of Fabricius}

Histopathological examination of bursae (group I) revealed hyperplasia of the follicular epithelium with multiple small epithelial cysts associated with subepithelial oedema in the follicular stroma infiltrated with mononuclear inflammatory cells (Fig. 1a). Moreover, the proliferation of interfollicular connective tissue was severe and infiltrated with mononuclear cells in most of the examined cases (Fig. 1b). The reticule-epithelial layer of the bursal follicles was not evident with the appearance of remnants from mats of fibrin in depleted bursal lymphoid follicles (Fig. 1c). There is a marked epithelization in the bursal follicles which formed multiple cysts (Fig. 1d). Formation of large medullary cysts containing cellular debris and pretentious material in their lumen was recorded in some cases (Fig. 1e).

The amelioration in immune reaction became very evident in group II and group III. The prominent reactive hyperplasia of the follicular epithelium associated with mononuclear inflammatory cells infiltration was seen in subepithelial connective tissue in (group II) (Fig. 2a). The lymphoid follicles were enlarged and tightly packed with cortical and medullary lymphocytes in addition to prominent medullary lymphoblastic and macrophage cellular proliferation accompanied with an enfolded follicular reticuloepithelial layer in some follicles in group III (Fig. 2b).

In group IV, the examined bursae showed mild lymphoid depletion of medullary lymphocytes associated with a proliferation of the interfollicular stroma and infiltrated with macrophages and a small number from heterophils with epithelial cysts in the hyperplastic epithelium (Fig. 2c). In other cases, in addition to the findings mentioned above, there is interstitial haemorrhage (Fig. 2d). Epithelised follicular cysts were observed in a small number of bursal follicles in some cases (Fig. 2e). Solitary pyogranulomatous foci of bacterial origin were found in one case which were characterised by a central necrotic mass of granulocytes surrounded by a connective tissue capsule (Fig. 2f).

The histopathological scoring of bursa of Fabricius of chicken which was examined in all four groups was demonstrated in Table 1.

\section{Trachea}

The trachea of (group I) showed desquamation of tracheal epithelium with a collection of tissue debris and fibrinous material infiltrated with inflammatory cells in the tracheal lumen in some cases (Fig. 3a). 

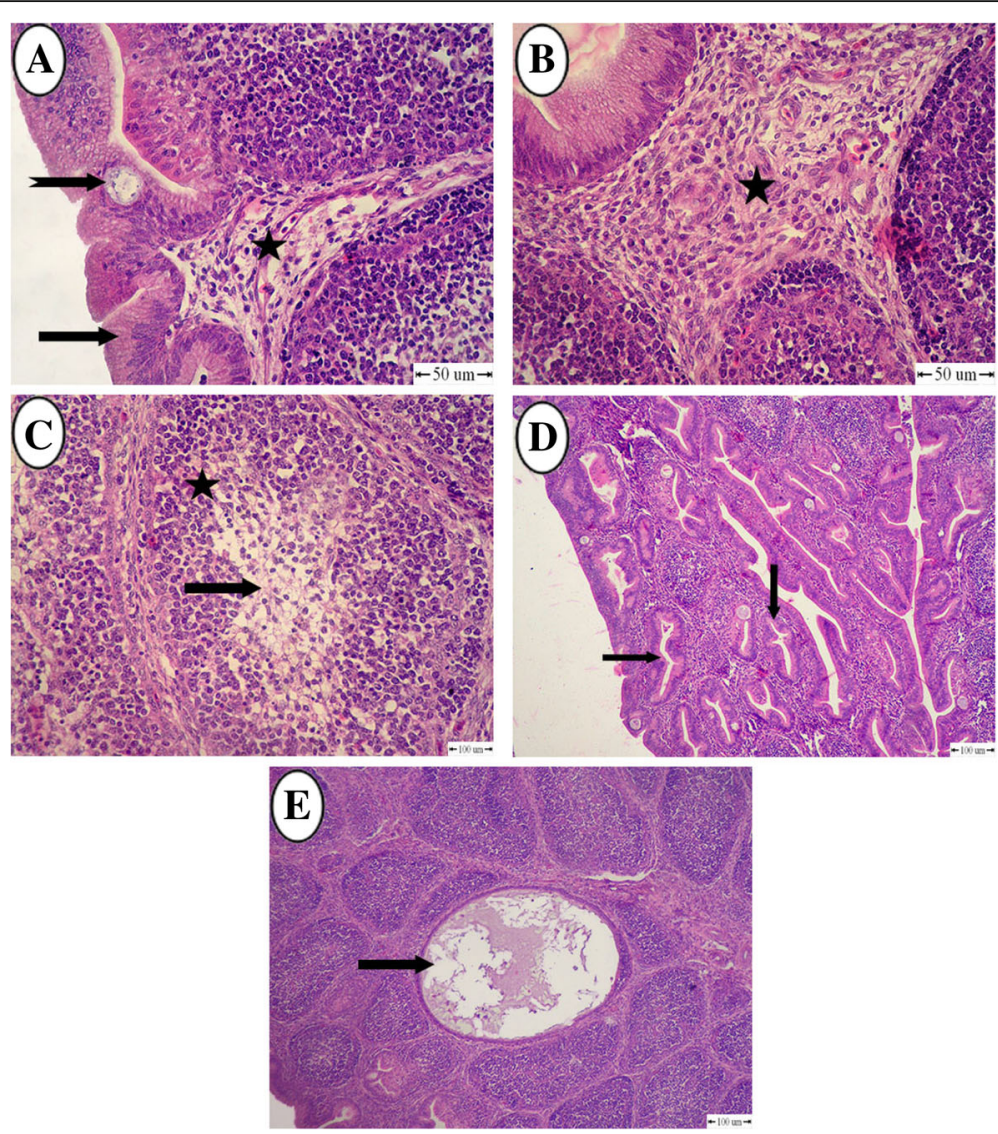

Fig. 1 a The examined bursae from chicken in group I showing hyperplasia of the follicular epithelium (arrow), multiple small epithelial cysts (notched arrow) with subepithelial edema and infiltrated with inflammatory cells (star), bar $=50$. b Proliferation of the inter-follicular stromal connective tissue and infiltrated with mononuclear cells (star), bar $=50$. c Depletion of the bursal follicles (star) with remnants of fibrin (arrow), bar $=50$ (H\&E). d There is a marked epithelisation of the follicular structures which formed multiple cysts (arrow), bar $=100$. e Presence of large medullary cysts filled with cellular debris and pretentious material (arrow), bar $=100$ (H\&E)

In the examined trachea of chickens of (group II), slight desquamation of tracheal epithelium with deciliation was observed (Fig. 3b). In group III, there is hyperplasia of epithelium accompanied with infiltration of lamina propria with lymphocytes and heterophils as an immune activity with slight oedema (Fig. 3c).

Deciliation with proliferation of undifferentiated epithelium infiltrated with heterophils and mononuclear inflammatory cells was observed in group IV (Fig. 3d). These lesions were accompanied with hemorrhagic tracheitis characterised by slight haemorrhage with infiltration of inflammatory cells in the lamina propria (Fig. 3e).

The histopathological scoring of the trachea of chicken which was examined in all four groups was demonstrated in Table 2.

\section{Immunohistochemistry}

CD79A-positive cells distributed mainly in the medulla of lymphoid follicles in bursa, while in cortex, it was immature cells (Fig. 4a). CD79A-positive cells in bursa of group I showed a weak reaction and depleted cells (Fig. 4b).

The immune reaction increased slightly in the cortex of lymphoid follicles in bursa of Fabricius of broiler chickens in group II (Fig. 4c). In group III, immuno-stained sections of lymphoid follicles in bursa showed a strong positive reaction (Fig. 4d) while it was moderate in group IV (Fig. 4e).

The comparing data presented in (Table 3) showed the mean number of CD79A-positive cells. The mean number of CD79A-positive cells was significantly higher in group III (34.25 $\pm(3.77))$ in comparison to other groups. The quantification of CD79A-positive cells was statistically higher $(P<0.003)$ (Fig. 5).

\section{Discussion}

Histopathological examination of bursa from group I showed some immunological reactions. This reaction may be due to the natural protective effect of the immune system. These immunological reactions agree with Ezeokoli, Ityondo, Nwannenna, and Umoh (1990). 

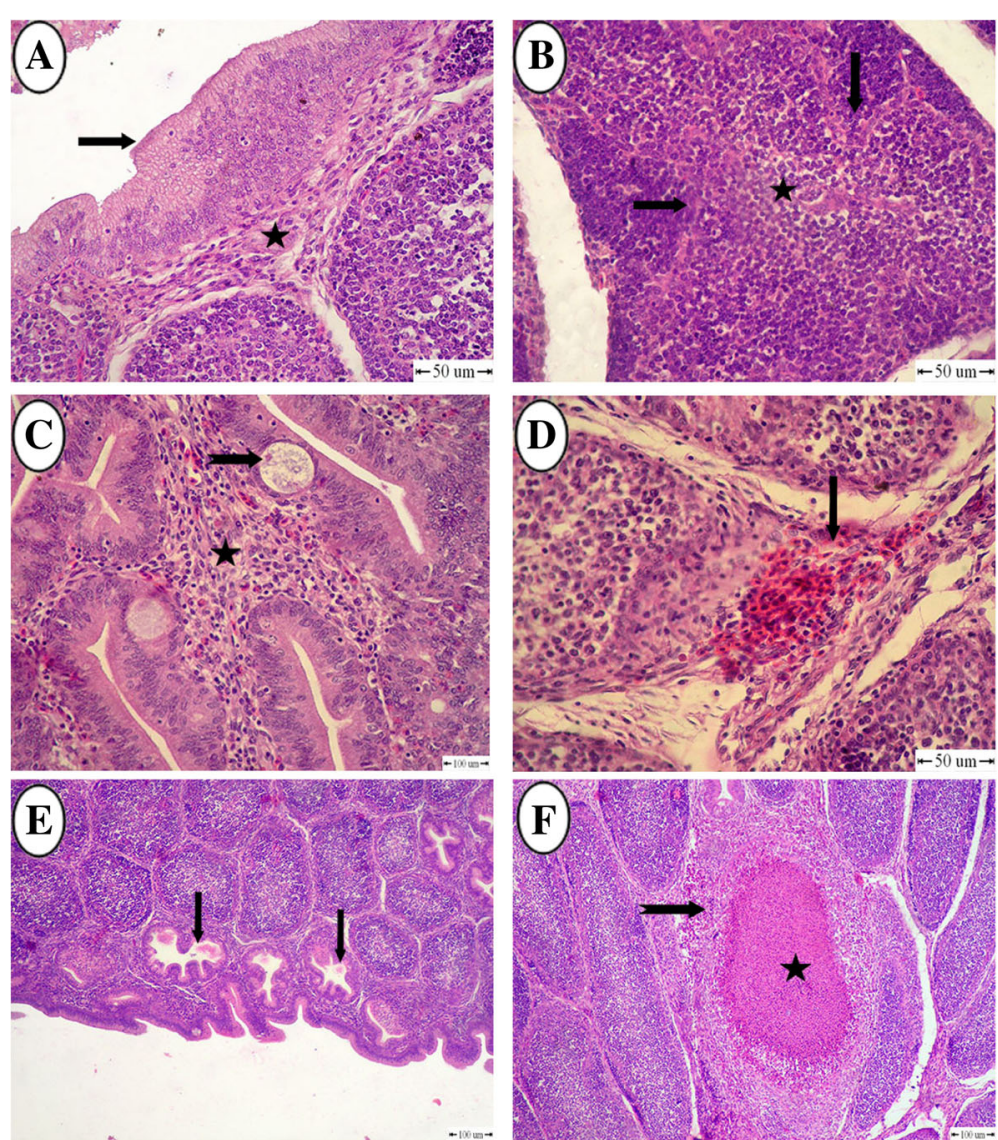

Fig. 2 a The examined bursae from chickens in group II showing hyperplasia of the follicular epithelium (arrow) associated with mononuclear infiltration in subepithelial connective tissue (star), bar $=50$. b The examined bursae in chickens of group III showing enlarged and tightly packed lymphoid follicles with cortical and medullary lymphocytes (star) with enfolded follicular reticuloepithelial layer (arrow), bar $=50$. $\mathbf{c}$ In the bursae, obtained from group IV showing proliferation of the inter-follicular stroma infiltrated with inflammatory cells (star) and epithelial cysts in the hyperplastic epithelium (notched arrow), bar $=100$. $\mathbf{d}$ Interstitial haemorrhage (arrow), bar $=50$. e The epithelized cysts observed in few follicles (arrow), bar $=100 . \mathbf{f}$ Formation of pyogranuloma (notched arrow) with necrotic center (star), bar =100. (H\&E)

Table 1 The histopathological scoring of bursa of Fabricius of chicken examined in all four groups

\begin{tabular}{|c|c|c|c|c|}
\hline & Group I & Group ॥ & Group III & Group IV \\
\hline Hyperplasia of bursal epithelium & $\begin{array}{l}12 \text { birds }^{a} \\
+++^{b}\end{array}$ & $\begin{array}{l}18 \text { birds }^{a} \\
+++^{b}\end{array}$ & $\begin{array}{l}20 \text { birds }^{a} \\
+++^{b}\end{array}$ & $\begin{array}{l}20 \text { birds }^{\mathrm{a}} \\
+++^{\mathrm{b}}\end{array}$ \\
\hline Thickening of interfollicular stroma with inflammatory cellular infiltration & $\begin{array}{l}10 \text { birds }^{a} \\
+++^{b}\end{array}$ & $\begin{array}{l}16 \text { birds }^{a} \\
+++^{b}\end{array}$ & $\begin{array}{l}18 \text { birds }^{a} \\
+++^{b}\end{array}$ & $\begin{array}{l}20 \text { birds }^{\mathrm{c}} \\
+++^{\mathrm{b}}\end{array}$ \\
\hline Lymphoid depletion of lymphoid follicles & $\begin{array}{l}20 \text { birds }^{a} \\
++^{b}\end{array}$ & $\begin{array}{l}12 \text { birds }^{a} \\
++^{b}\end{array}$ & $\begin{array}{l}10 \text { birds }^{\mathrm{a}} \\
++^{\mathrm{b}}\end{array}$ & $\begin{array}{l}13 \text { birds } \\
++^{\mathrm{b}}\end{array}$ \\
\hline Tightly packed lymphoid follicles & $\begin{array}{l}9 \text { birds }^{a} \\
++^{b}\end{array}$ & $\begin{array}{l}13 \text { birds }^{a} \\
++^{b}\end{array}$ & $\begin{array}{l}16 \text { birds }^{\mathrm{a}} \\
+++^{\mathrm{b}}\end{array}$ & $\begin{array}{l}12 \text { birds }^{\mathrm{c}} \\
+++^{\mathrm{b}}\end{array}$ \\
\hline Epithelised follicular cysts & $\begin{array}{l}19 \text { birds }^{a} \\
++++^{b}\end{array}$ & $\begin{array}{l}8 \text { birds }^{a} \\
+++^{b}\end{array}$ & $\begin{array}{l}15 \text { bird }^{a} \\
t^{b}\end{array}$ & $\begin{array}{l}13 \text { birds } \\
++^{b}\end{array}$ \\
\hline Medullary cyst & $\begin{array}{l}15 \text { birds }^{a} \\
+++^{b}\end{array}$ & $\begin{array}{l}11 \text { birds }^{a} \\
++^{b}\end{array}$ & $\begin{array}{l}0^{a} \\
0^{b}\end{array}$ & $\begin{array}{l}20 \text { birds }^{\mathrm{c}} \\
+++^{\mathrm{b}}\end{array}$ \\
\hline Pyogranuloma & $\begin{array}{l}0^{\mathrm{a}} \\
0^{\mathrm{b}}\end{array}$ & $\begin{array}{l}0^{\mathrm{a}} \\
0^{\mathrm{b}}\end{array}$ & $\begin{array}{l}0^{\mathrm{a}} \\
0^{\mathrm{b}}\end{array}$ & $\begin{array}{l}1 \text { bird }^{a} \\
++^{b}\end{array}$ \\
\hline
\end{tabular}

${ }^{a}$ Number of examined birds

${ }^{\mathrm{b}}$ The severity degree of lesions designated as follows (Muskett et al., 1979): complete loss of follicular architecture and fibroplasias +++++, very severe ++++, severe +++ , moderate ++ , mild + , no damage 0 

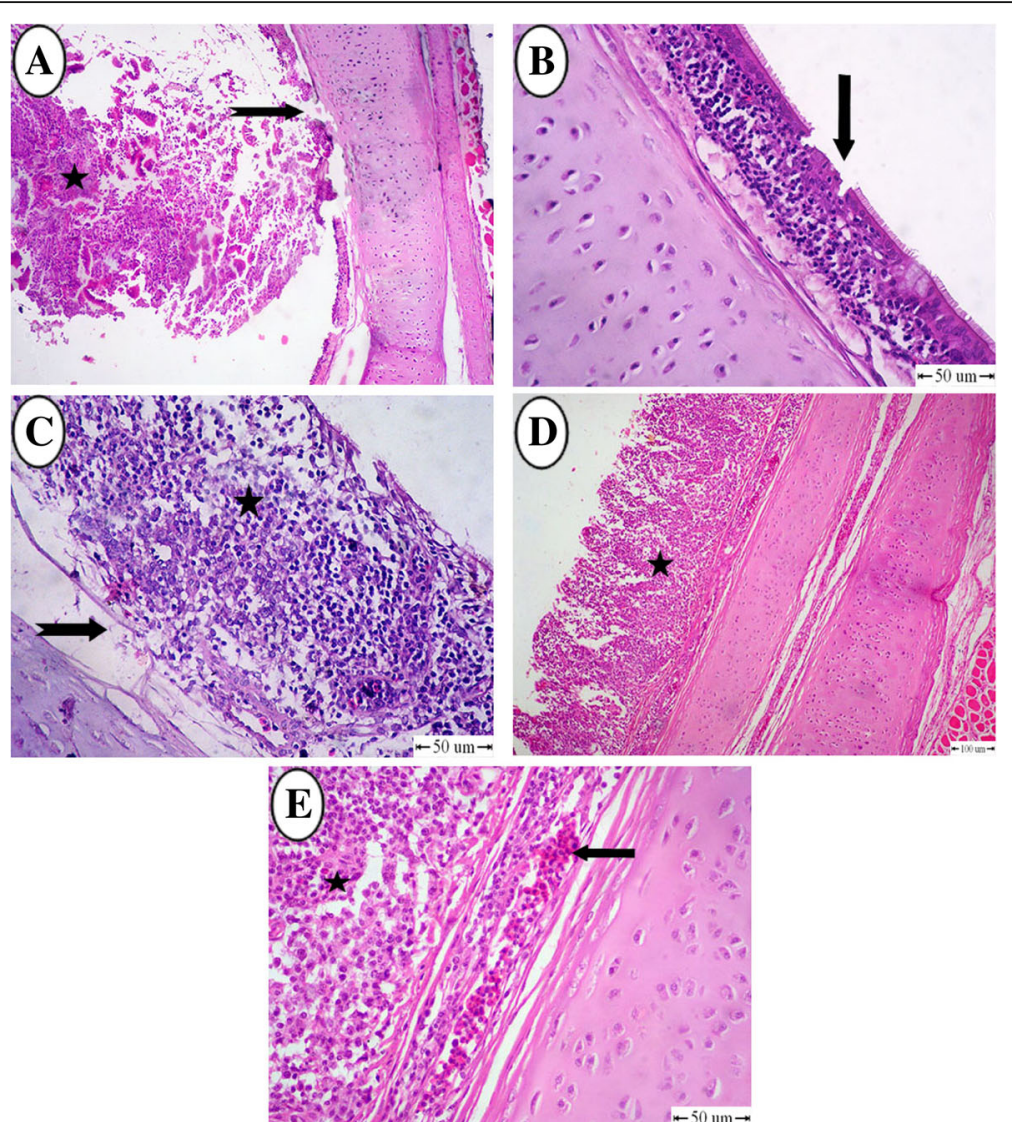

Fig. 3 a Histopathological examination of the trachea from chicken in group I showing desquamation of tracheal epithelium (notched arrow) and collection of tissue debris and fibrinous material infiltrated with inflammatory cells in the tracheal lumen (star) $\times 4$. $\mathbf{b}$ The examined trachea of chickens of group II showing deciliation with desquamation of tracheal epithelium (arrow), bar =50. $\mathbf{c}$ The examined trachea of chickens of group III showing hyperplasia of the epithelial layer cells infiltrated with inflammatory cells in the trachea (star) and oedema into the lamina propria (notched arrow), bar $=50$. $\mathbf{d}$ In the trachea, obtained from (group IV) showing deciliation with proliferation of undifferentiated epithelium infiltrated with inflammatory cells (star), bar = 100. e In the higher magnification, infiltration of epithelium with inflammatory cells (star) accompanied with haemorrhage and infiltration of inflammatory cells in the lamina propria (arrow), bar $=50$.(H\&E)

Table 2 The histopathological scoring of trachea of chicken examined in all four groups

\begin{tabular}{lllll}
\hline & Group I & Group II & Group III & Group IV \\
\hline Epithelial injuery & 8 birds $^{\mathrm{a}}$ & 4 birds $^{\mathrm{a}}$ & 3 birds $^{\mathrm{a}}$ & 2 birds $^{\mathrm{b}}$ \\
& $3^{\mathrm{b}}$ & $2^{\mathrm{b}}$ & $1^{\mathrm{b}}$ & $2^{\mathrm{b}}$ \\
Submucosal inflammation & 13 birds $^{\mathrm{a}}$ & 10 birds $^{\mathrm{a}}$ & 8 birds $^{\mathrm{a}}$ & 11 birds $^{\mathrm{a}}$ \\
& $2^{\mathrm{b}}$ & $1^{\mathrm{b}}$ & $2^{\mathrm{b}}$ & $3^{\mathrm{b}}$ \\
Submucosal oedema & 8 birds $^{\mathrm{a}}$ & 7 birds $^{\mathrm{s}}$ & 8 birds $^{\mathrm{z}}$ & 13 birds $^{\mathrm{b}}$ \\
& $2^{\mathrm{b}}$ & $1^{\mathrm{b}}$ & $1^{\mathrm{b}}$ & $++^{\mathrm{b}}$ \\
Submucosal haemorrhage & 6 birds $^{\mathrm{a}}$ & 2 birds $^{\mathrm{a}}$ & 0 bird $^{\mathrm{a}}$ & 5 birds $^{\mathrm{b}}$ \\
& $1^{\mathrm{b}}$ & $1^{\mathrm{b}}$ & $0^{\mathrm{b}}$ & $2^{\mathrm{b}}$ \\
\hline
\end{tabular}

${ }^{\mathrm{a} N u m b e r}$ of examined birds

${ }^{\mathrm{b}}$ The severity degree of lesions designated as follows (Reali-Forster et al., 1996): the epithelial injury, no damage $=0$, mild $=1$, moderate $=2$ and severe $=3$. Submucosal edema, inflammation and haemorrhage: absent $=0$, mild $=1$, moderate $=2$ and severe $=3$
The depletion of other bursal follicles was moderate, and according to some studies, the depletion of lymphoid follicles resulted from necrosis of these cells by the effect of a live vaccine (Zubeedy, Shamaun, \& Al-Aalim, 2013). While other studies said that, the increase in the severity of depletion of bursal follicles might be due to the failure of vaccines to induce protective immunity which attributed to interference of maternal antibodies with the vaccine virus in addition to the direct immunosuppressive action of the vaccine. This effect by a vaccine is suggested that immunosuppression may be a result of direct histological damage to the bursa (Muskett et al., 1979). The simultaneous multiplication of vaccine virus with a production of antibodies in the bursa may produce immune complexes causing cellular damage due to activation of complement (Ezeokoli et al., 1990). There is a marked epithelisation of the follicles with the formation of multiple cysts recorded in some cases. These results are usually associated with the direct 


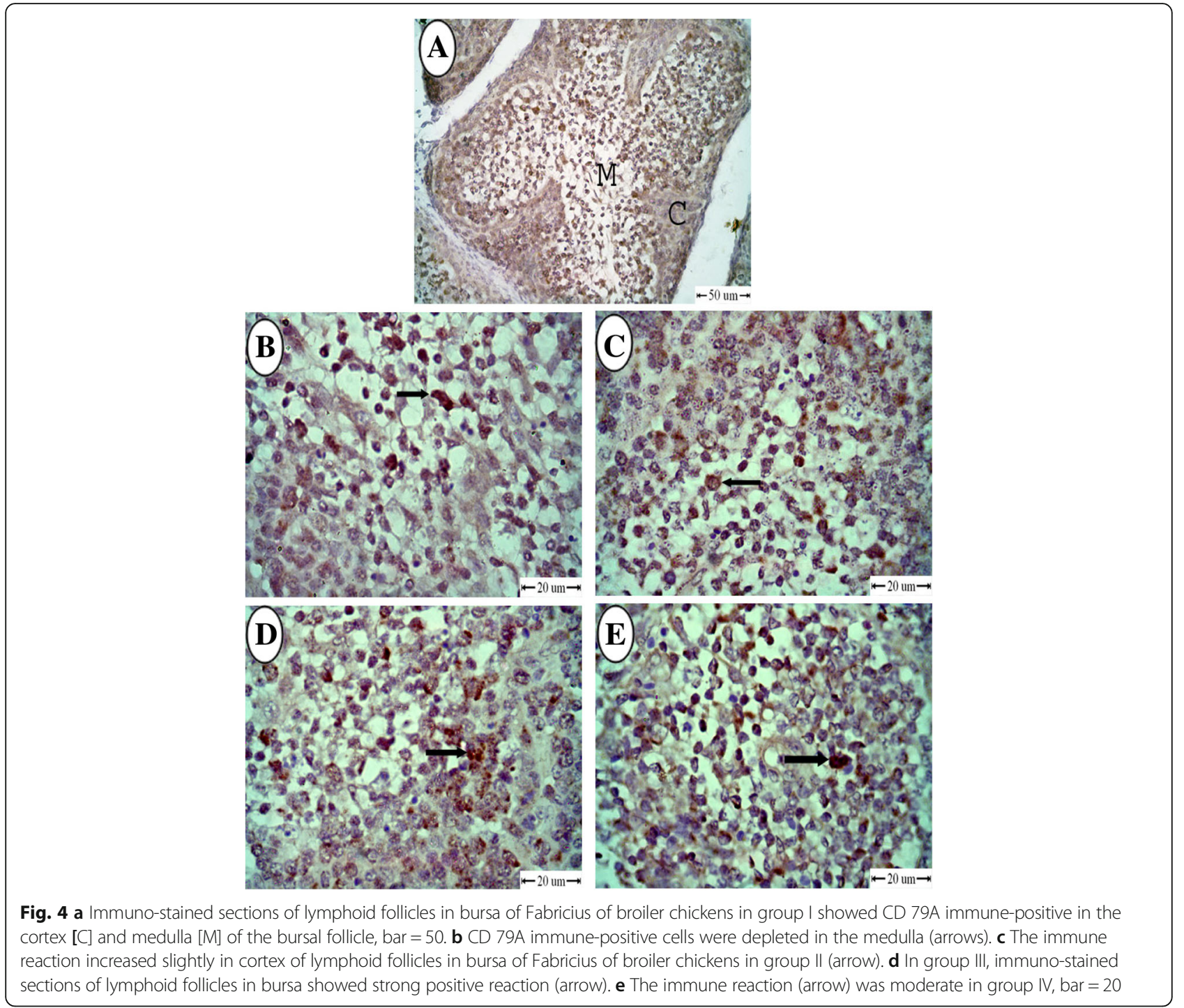

effect of Newcastle disease virus and IBD viral infection according to Qubih and Mohammadamin (2011).

The examined bursae of chickens of group II and group III showed reactive lymphoid follicles. The increase of immune cells in group II was because of the oregano essential oils which have a potent antioxidant effect supporting the rise of $\mathrm{T}$ lymphocyte in pigs fed with oregano (Rhee et al., 1996; Walter \& Bilkei, 2004).

Table 3 Mean number of CD79A-positive cells in bursa of Fabricious in broiler chicken in the experimental groups

\begin{tabular}{ll}
\hline Groups & Mean \pm SD \\
\hline Group I & $14.25 \pm 2.75$ \\
Group II & $25.75 \pm 2.63$ \\
Group III & $34.25 \pm 3.77$ \\
Group IV & $17.75 \pm 0.96$ \\
\hline
\end{tabular}

$\beta$-glucans in oregano essential oils activate the immune cells, macrophages, dendritic cells neutrophils, B cells, T cells and natural killer cells (Kim et al., 2011). This immune reaction was most apparent in group III due to the potentiating action of selenium on the immune system. Selenium, when added to chickens infected with coccidia, created changes in the numbers of blood leucocytes, revealing that Se possibly improves resistance to infection (Colnago, Jensen, \& Long, 1984). Vitamin E in $\mathrm{D}$ - $\alpha$-tocopherol vitamin in turkey embryos' diet may have an immunomodulatory effect which increases the resistance against infection, and this is according to Gore and Qureshi (1997). Haq, Bailey, and Chinnah (1996) studied the effect of vitamin E supplementation on hatched chicks from breeders fed diets supplemented with vitamin $\mathrm{E}$; the tetrahydrofuran-stimulated bursal lymphocyte proliferation and phorbol 12-myristate 13-acetate-stimulated splenic lymphocyte proliferation 


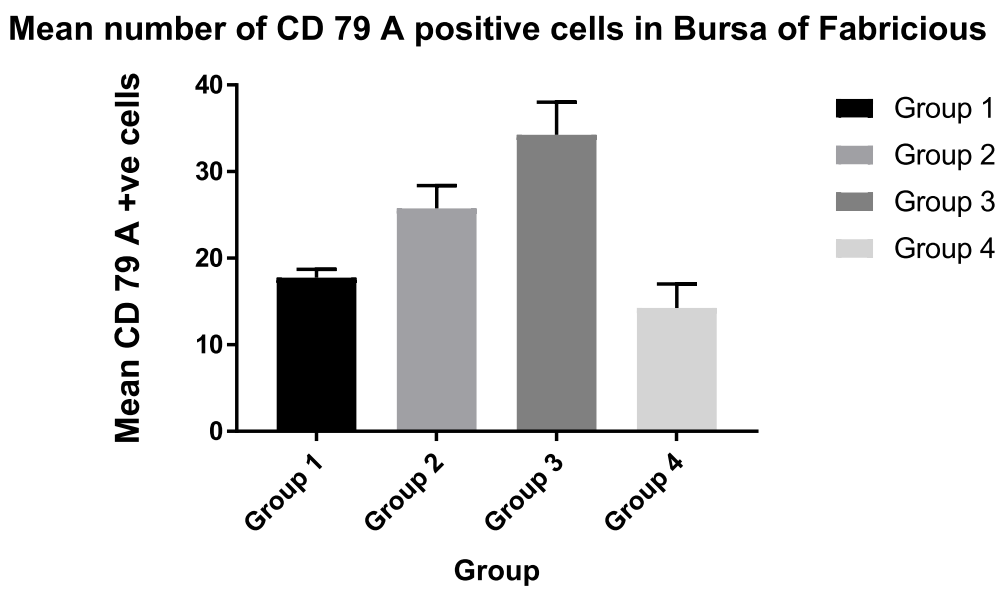

Fig. 5 Quantification of CD79A-positive cells in bursa of Fabricius of chickens; the values are given as the mean \pm standard error

were higher than in control chicks, and this means that the immunostimulatory effects of vitamin E supplementation seem to be transferred to the offspring. On the other hand, Leshchinsky \& Klasing (2001) discovered that the increase in the antibody titers of broilers depends on the amount of vitamin $E$ which is injected and needed for the inhibition of lipid peroxidation and for the protection of liver mitochondria against oxidative stress, and they found that moderate vitamin E levels promoted better immunomodulation than high vitamin E levels.

In the examined bursae, obtained from chicken in group IV, the lesions consisted of mild depletion of medullary lymphocytes associated with a proliferation of the interfollicular stroma infiltrated with prominent macrophages and few heterophils. The cellular immune reaction which observed agreed with Ichinohe et al. (2011). Abt et al. (2012) previously confirmed that commensal bacterial lipopolysaccharide could interact with the host's immune system to protect against avian influenza virus pathogenesis. These results were suggesting that interaction with LPS is highly dependent on the virion structure according to Robinson, Jesudhasan, and Pfeiffer (2014).

In this study, we identified primary antibodies (anti-chicken CD79A) in the bursa of all birds. According to con Gumboro (2012), the maximum number of lymphocytes was depleted in the bursa of Fabricius than the spleen and thymus of Gumboro-infected broilers, among the major lymphoid organs. In our study, the morphometrical analysis of detected positive B lymphocytes in immune stained sections of lymphoid follicles in the bursa of Fabricius showed that the quantification of positive B lymphocytes was significantly higher in group III in comparison to other groups. This, due to the combination of selenium and vitamin E, plays a significant role in the development and maintenance of defence systems. Vitamin E raises the bird resistance as it has an active role in regulatory actions on the immune system as well as minimises the level of pathology resulting from cytotoxic immune responses (Klasing, 1998).

Vitamin $E$ reduces enzymatic oxidation and nucleic acid metabolism (Franchini et al., 1991). Vitamin E has been shown to increase antibody production by improving the humoral immune response or by acting as an adjuvant. Dietary vitamin E supplementation enhanced the number of plaque-forming cells and hemagglutination titers following immunisation with sheep red blood cells and tetanus toxoid in mice (Nockels, 1979).

Tracheal lesions in group I were expressed by fibrinous tracheitis. These results were typical pathological characters of the avian influenza virus infection according to Gao et al. (2016). These lesions decreased in group II. In addition to the decrease of tracheal damage, there is immune response in group III which indicates the ameliorating effect of vitamin E. Vitamin E decreases the synthesis of prostaglandins, leukotrienes and cytokines, which are responsible for the regulation of the inflammatory response reducing damage caused to the tissues by the inflammatory process (Klasing, 1998).

\section{Conclusion}

The present study was conducted to evaluate the effect of different immunomodulators on the immune response in chicken. Imutrix ${ }^{\bullet}$ and vitamin E plus selenium decreased the bursal and tracheal damage more than Immunair 17.5. Furthermore, the number of CD 79A was significantly higher due to the effect of vitamin $\mathrm{E}$ plus selenium.

\section{Abbreviations}

Al: Avian influenza; Anti-SRBC titer: Antibody sheep red blood cells titer; CD 79A: B cell antigen receptor complex-associated protein alpha chain; DAB chromogen: 3,3'-Diaminobenzidine chromogen; E. coli: Escherichia coli; IBD: Infectious bursal disease; IL-1: Interleukin-1; IL-6: Interleukin-6; 
LPS: Lipopolysaccharides of Escherichia coli; ND: Newcastle disease; OEO: Oregano essential oils; P. acnes: Propionibacterium acnes; PBS: Phosphate-buffered saline; Poly HRP: Poly-horseradish peroxidase; TNF: Tumour necrosis factor

\section{Acknowledgements}

We would like to express my sincerest gratitude and appreciation to financial support faculty of Veterinary Medicine, Assiut University, Assiut, Egypt.

\section{Funding}

There are no external sources of funding for this work except institutions to which the authors were joined.

\section{Availability of data and materials}

All the data and materials used to reach the conclusion of this study are available from the corresponding author on reasonable request.

\section{Authors' contributions}

All authors suggested the study, participated in its design and coordination, interpreted the results, and approved the final manuscript.

\section{Ethics approval and consent to participate}

This study was approved by the Social Science Ethical Committee of the Faculty of Veterinary medicine, Assiut University, Assiut, Egypt.

All applicable international, national, and institutional guidelines for the care and use of birds were followed.

\section{Consent for publication}

Not applicable.

\section{Competing interests}

The authors declare that they have no competing interests.

\section{Publisher's Note}

Springer Nature remains neutral with regard to jurisdictional claims in published maps and institutional affiliations.

\section{Author details}

${ }^{1}$ Department of pathology and clinical pathology, Faculty of Veterinary Medicine, Assiut University, Assiut 71526, Egypt. ${ }^{2}$ Department of poultry diseases, Faculty of Veterinary Medicine, New Valley University, New Valley, Egypt. ${ }^{3}$ Department of poultry diseases, Faculty of Veterinary Medicine, Assiut University, Assiut, Egypt.

\section{Received: 11 October 2018 Accepted: 4 January 2019}

Published online: 25 January 2019

\section{References}

Abt, M. C., Osborne, L. C., Monticelli, L. A., Doering, T. A., Alenghat, T. Sonnenberg, G. F., ... Erikson, J. (2012). Commensal bacteria calibrate the activation threshold of innate antiviral immunity. Immunity, 37(1), 158-170.

Al-Bandak, G., \& Oreopoulou, V. (2007). Antioxidant properties and composition of Majorana syriaca extracts. European Journal of Lipid Science and Technology, 109(3), 247-255.

Anis, Z., Morita, T., Azuma, K., Ito, H., Ito, T., \& Shimada, A. (2013). Comparative study on the pathogenesis of the generated 9a5b Newcastle disease virus mutant isolate between chickens and waterfowl. Veterinary Pathology, 50(4), 638-647.

Bancroft, J. D., \& Stevens, A. (1982). Theory and practice of histological techniques. NY: Churchill Livingstone.

Colnago, G. L., Jensen, L. S., \& Long, P. L. (1984). Effect of selenium and vitamin E on the development of immunity to coccidiosis in chickens. Poultry Science, 63(6), 1136-1143. https://doi.org/10.3382/ps.0631136.

con Gumboro, E. I. N. (2012). Distribution and quantification of lymphocytes in the major lymphoid organs of naturally gumboro infected broilers. International Journal of Morphology, 30(4), 1585-1589.

Dhama, K., Chakraborty, S., Mahima, W. M., Verma, A. K., Deb, R., Tiwari, R., \& Kapoor, S. (2013). Novel and emerging therapies safeguarding health of humans and their companion animals: a review. Pakistan Journal of Biological Sciences, 16(3), 101-111.
Ezeokoli, C., Ityondo, E., Nwannenna, A., \& Umoh, J. (1990). Immunosuppression and histopathological changes in the bursa of Fabricius associated with infectious bursal disease vaccination in chicken. Comparative Immunology, Microbiology and Infectious Diseases, 13(4), 181-188.

Franchini, A., Canti, M., Manfreda, G., Bertuzzi, S., Asdrubali, G., \& Franciosi, C. (1991). Vitamin E as adjuvant in emulsified vaccine for chicks. Poultry Science, 70(8), 1709-1715

Gao, R., Bai, T., Li, X., Xiong, Y., Huang, Y., Pan, M., ... Shu, Y. (2016). The comparison of pathology in ferrets infected by H9N2 avian influenza viruses with different genomic features. Virology, 488, 149-155.

Gore, A., \& Qureshi, M. (1997). Enhancement of humoral and cellular immunity by vitamin E after embryonic exposure. Poultry Science, 76(7), 984-991.

Haq, A.-U., Bailey, C. A., \& Chinnah, A. (1996). Effect of $\beta$-carotene, canthaxanthin, lutein, and vitamin $E$ on neonatal immunity of chicks when supplemented in the broiler breeder diets. Poultry Science, 75(9), 1092-1097.

Hou, R., Chen, J., Yue, C., Li, X., Liu, J., Gao, Z., ... Li, H. (2016). Modification of lily polysaccharide by selenylation and the immune-enhancing activity. Carbohydrate Polymers, 142, 73-81

Ichinohe, T., Pang, I. K., Kumamoto, Y., Peaper, D. R., Ho, J. H., Murray, T. S., \& Iwasaki, A. (2011). Microbiota regulates immune defense against respiratory tract influenza A virus infection. Proceedings of the National Academy of Sciences, 108(13), 5354-5359.

Inc, S. (2007). Released 2007. SPSS for Windows, version 16.0. Chicago: SPSS Inc.

Khan, R., Rahman, Z., Nikousefat, Z., Javdani, M., Tufarelli, V., Dario, C., ... Laudadio, V. (2012). Immunomodulating effects of vitamin E in broilers. World's Poultry Science Journal, 68(1), 31-40.

Kim, J., Lee, S. M., Bae, I. Y., Park, H. G., Gyu Lee, H., \& Lee, S. (2011). (1-3)(1-6)- $\beta$ Glucan-enriched materials from Lentinus edodes mushroom as a high-fibre and low-calorie flour substitute for baked foods. Journal of the Science of Food and Agriculture, 91(10), 1915-1919.

Klasing, K. (1998). Nutritional modulation of resistance to infectious diseases. Poultry Science, 77(8), 1119-1125.

Konjufca, V., Bottje, W., Bersi, T., \& Erf, G. (2004). Influence of dietary vitamin $E$ on phagocytic functions of macrophages in broilers. Poultry Science, 83(9), 1530-1534.

Leshchinsky, T., \& Klasing, K. (2001). Relationship between the level of dietary vitamin $\mathrm{E}$ and the immune response of broiler chickens. Poultry Science, 80(11), 1590-1599.

Martín-Rabadán, P., Gijón, P., Alcalá, L., Rodríguez-Créixems, M., Alvarado, N., \& Bouza, E. (2008). Propionibacterium acnes is a common colonizer of intravascular catheters. Journal of Infection, 56(4), 257-260.

Muskett, J., Hopkins, I., Edwards, K., \& Thornton, D. (1979). Comparison of two infectious bursal disease vaccine strains: efficacy and potential hazards in susceptible and maternally immune birds. The Veterinary Record, 104(15), 332-334

Nockels, C. F. (1979). Protective effects of supplemental vitamin E against infection. Federation Proceedings, 38(7), 2134-2138.

Qubih, T., \& Mohammadamin, O. (2011). Histopathology of virulent Newcastle disease virus in immune broiler chickens treated with IMBO ${ }^{\oplus}$. Iraqi Journal of Veterinary Sciences, 25(1), 9-13.

Reali-Forster, C, Kolobow, T, Giacomini, M, Hayashi, T., Horiba, K. \& Ferrans, V. J. (1996). New ultrathin-walled endotracheal tube with a novel laryngeal seal design: long-term evaluation in sheep. Anesthesiology: the journal of the American Society of Anesthesiologists, 84(1), 162-172.

Rhee, K., Anderson, L., \& Sams, A. (1996). Lipid oxidation potential of beef, chicken, and pork. Journal of Food Science, 61(1), 8-12.

Robinson, C. M., Jesudhasan, P. R., \& Pfeiffer, J. K. (2014). Bacterial lipopolysaccharide binding enhances virion stability and promotes environmental fitness of an enteric virus. Cell Host \& Microbe, 15(1), 36-46.

Silhavy, T. J., Kahne, D., \& Walker, S. (2010). The bacterial cell envelope. Cold Spring Harbor Perspectives in Biology: 10.1101.

Tizard, I. R. (2009). Inmunología veterinaria, (8th ed., ). Barcelona: Elsevier Saunders.

Volman, J. J., Ramakers, J. D., \& Plat, J. (2008). Dietary modulation of immune function by beta-glucans. Physiology \& Behavior, 94(2), 276-284. https://doi. org/10.1016/j.physbeh.2007.11.045

Walter, B. M., \& Bilkei, G. (2004). Immunostimulatory effect of dietary oregano etheric oils on lymphocytes from growth-retarded, low-weight growing-finishing pigs and productivity. Tijdschrift voor Diergeneeskunde, 129(6), 178-181.

Weibel, E. R. (1969). Stereological Principles for Morphometry in Electron Microscopic Cytology1. In International review of cytology (Vol. 26, pp. 235302). Academic Press. 
Yamuna, K., \& Thangavel, A. (2011). Effect of selenium and vitamin E supplementation on immune status in broiler chickens. Tamilnadu Journal Veterinary and Animal Sciences, 7(6), 303-306.

Yu, J., Shi, F. S., \& Hu, S. (2015). Improved immune responses to a bivalent vaccine of Newcastle disease and avian influenza in chickens by ginseng stem-leaf saponins. Veterinary Immunology and Immunopathology, 167(3-4), 147-155. https://doi.org/10.1016/j.vetimm.2015.07.017.

Zubeedy, A. A., Shamaun, A., \& Al-Aalim, A. (2013). Histopathological and immune response against infectious bursal disease in chickens vaccinated against Newcastle disease. AL-Qadisiyah Journal of Veterinary Medicine Sciences, 12(1), $66-70$

Submit your manuscript to a SpringerOpen ${ }^{\circ}$ journal and benefit from:

- Convenient online submission

- Rigorous peer review

- Open access: articles freely available online

- High visibility within the field

- Retaining the copyright to your article

Submit your next manuscript at $\boldsymbol{\nabla}$ springeropen.com 